\section{Quality of life of medical students in Brazil. A comparative study}

\author{
RINALDO ANTUNES BARROS ${ }^{1}$, \\ MARTA SILVA MENEZES ${ }^{1}$, LILIANE LINS ${ }^{2}$
}

\begin{abstract}
Background: VERAS survey multicenter project, carried out in 2011-2012, evaluated the quality of life (QoL) of students from 22 Brazilian medical schools. Aim: To evaluate QoL of undergraduate medical students, taking Veras- $q$ national data as comparison. Material and Methods: We evaluated the QoL of 197 medical students in a Brazilian private medical school at Salvador, Bahia, Brazil in 2014. Students in the first two years were grouped in Phase I; those in years three and four were grouped in Phase II. Those in the internship (fifth and sixth years) were grouped in Phase III. Results: Students from Phase I group had better QoL averages than those from Phase II. Phase I students presented significantly $(p<0.05)$ better scores in the Psychological and Use of Time domains. Compared to Phase II students, those in Phase III obtained better scores in the Physical and Environmental domains. Female students had significantly lower $(p<0.01)$ scores than male students in Physical, Psychological and Use of Time domains. Compared to the national sample survey, these students had higher $(p<0.01)$ scores in all domains, except for the Physical domain in Phase II ( $p<0.4352)$. Conclusions: These students had a better quality of life than those surveyed in the national Veras-q study. Female students had lower scores. Adjusted schedules and lower work overload, as consequences of effective interdisciplinarity in curricular components, may have contributed to higher students' QoL.
\end{abstract}

(Rev Med Chile 2019; 147: 107-113)

Key words: Curriculum; Education, Medical; Students, Medical; Quality of Life9.

\section{Calidad de vida de estudiantes de medicina en Brasil. Un estudio comparativo}

Antecedentes: El proyecto multicéntrico VERAS evaluó la calidad de vida de estudiantes de medicina en los años 2011-2012. Objetivo: Evaluar la calidad de vida de un grupo de estudiantes de medicina y compararla con los datos del proyecto VERAS. Material y Métodos: Se evaluó calidad de vida en 197 estudiantes de medicina de universidades privadas de Salvador, Bahía, Brasil en 2014. Los estudiantes de los dos primeros años fueron agrupados en la fase I, aquellos de tercer y cuarto año en fase II y los del internado en fase III. Resultados: Los estudiantes en fase I tuvieron mejor calidad de vida que aquellos en fase II. Los estudiantes en fase I tuvieron mejores puntajes en los dominios psicológico y uso
'Bahiana School of Medicine and Public Health, Salvador, Bahia, Brazil.

${ }^{2}$ School of Medicine, Federal University of Bahia, Salvador, Bahia, Brazil.

All co-authors fulfill the criteria of authorship and have critically reviewed and approved its last version of the paper for publication.

Liliane Lins, Rinaldo Antunes Barros and Marta Silva Menezes have written the paper, worked on acquisition, analysis and interpretation of data. Authors declare no conflict of interests.

Recibido el 10 junio de 2018, aceptado el 19 diciembre de 2018.

Correspondence to: Liliane Lins

School of Medicine, Federal University of Bahia.

Praça XV de Novembro, Largo do Terreiro de Jesus $\mathrm{s} / \mathrm{n}$ CEP 400260-10. Salvador, Bahia Brasil.

55-71-32835060.

Ikusterer@gmail.com 
del tiempo. Los estudiantes en fase III tuvieron mejores puntajes en los dominios físico y ambiental que los estudiantes en fase II. Las mujeres obtuvieron menores puntajes en los dominios físico, psicológico y uso del tiempo, que los hombres. Al comparar con el estudio nacional, estos estudiantes tuvieron mejores puntajes en todos los dominios, excepto el físico en estudiantes en fase II. Conclusiones: Estos estudiantes tuvieron mejor calidad de vida que sus pares estudiados previamente. Las mujeres tuvieron puntajes más bajos que los hombres. Una menor carga de trabajo, como consecuencia de un currículo multidisciplinario, puede haber influido en esta mejor calidad de vida.

T The quality of life has a complex definition. It comprises the perception of life, considering the culture and values related to the personal expectations and concerns ${ }^{1}$. Aspects of physical health, psychological state, the autonomy of the person, personal beliefs and relationship with the environment have been included in this complex definition ${ }^{2}$. Social relations and occupational distress may influence medical students' quality of life, influencing their development and performance ${ }^{3}$.

Educational environment factors constitute an important source of pressures that may lead to stress, such as long period of study, academic pressure, work overload and poor physical function. The relation of medical student distress with the practice of academic dishonesty, substance abuse, the decline of empathy and humanitarian skills has been demonstrated ${ }^{3}$. Medical students' health-related quality of life may be impaired mainly due to emotional aspects that affect their social relationships and daily activities ${ }^{4}$. Poor health-related quality of life has also been associated with sex, frequent headaches, sleepiness, lack of physical activity, and belonging to a student loan support program 4 .

Despite daily distress, the physician must be able to act at different levels of attention from the perspective of integral care, with a sense of social responsibility and commitment to citizenship ${ }^{5}$. Medical school curricula should establish well-defined objectives and goals, including knowledge, attitudes, and skills to prepare students to deal with suffering during medical training. Identifying factors that could impact medical students' quality of life is mandatory for designing and planning interventions that could enhance medical education and develop student resilience.

Brazilian Veras (Vida de Estudante e Residen- te na Área de Saúde) survey, was a multicenter project involving 1,350 medical students from 22 Brazilian medical schools, in 2011 and 2012, regarding quality of life of healthcare of students and residents. It aimed to understand the students' perceptions of the quality of life, as well as to investigate the teaching environment, considering cultural, social, temporal contexts and the determinants that could impact students' physical and mental health ${ }^{6}$.

This study aimed to evaluate the quality of life of undergraduate medical students from a Brazilian private medical school, using the questionnaire of the VERAS project (Veras-q) national data as comparison.

\section{Materials and Methods}

In 2014, a cross-sectional study evaluated the quality of life of medical students from the private institution in Salvador, State of Bahia, Brazil. The private institution medical course offers 100 new places each semester. The full-time course takes six years to complete and awards a generalist physician diploma.

The sample was stratified according to the period of the medical course; students in the first two years were denominated at Phase I; those in years three and four were in Phase II; and those in the internship (fifth and sixth years) were in Phase III.

The study methodology followed the same methodology used in the Veras-q national study, conducted in 2011-2012. The Veras-q instrument was developed in Brazil as a specific questionnaire to evaluate the medical student's quality of life. It presents five domains: General, Physical Health, Use of Time, Teaching and Psychological Environment. The questionnaire was administered to 
800 medical students from 75 Brazilian medical schools and it was validated, considering its internal consistence, discriminant and validity ${ }^{6}$.

In July 2014, 1,192 medical students from a private institution were regularly enrolled in medical course and were informed about the study. Formal explanations about the project were conducted in the institution during the first week of class, second term of 2014. We calculated sample size, using the OpenEpi v-3 tool for descriptive study. We estimated sample size in 291 medical students, considering the confidence limit of 5\% and the design effect of 1 . The questionnaires were formatted in the Survey Monkey Platform and sent to 291 medical students by institutional e-mails.

The quality of life of medical students (Veras-q) was accessed and their respective socio-demographic data were collected, including academic semester of the course, age, sex, family income and student's loan program. The Veras-q questionnaire was scored in a Likert scale of five points and scores are transformed in a scale from 0 (worst quality of life) to 100 (best quality of life). Cronbach's alpha coefficient was used to test reliability of the Veras- $q$ and a value of 0.7 or higher was considered satisfactory ${ }^{7}$.

Data were recorded in a databank using the Statistical Package for Social Sciences (SPSS) software, version 22.0. Normality of data was confirmed by Shapiro-Wilk test. The results were described by frequencies and the independent samples $t$ tests and Anova were used to compare means of independent groups.

The study was approved by the Ethics Review Board of the private institution under the Certificate of Presentation of Ethical Appreciation-CPEA: 30932514.7.0000.5544, protocol number 670.597 in accordance with National Council Resolution 466/12 and the Declaration of Helsinki 2013. All students were informed and agreed with electronic consent form approved by the Ethics Board.

\section{Results}

Of the 291 students, 197 enrolled in the academic second semester of 2014, filled the questionnaires with complete data (response rate of $68 \%)$ and the sample was stratified according to the period of the medical course (Phase I, Phase
II, and Phase III). Students characteristics are described in Table 1.

Cronbach's alpha coefficient (0.919) showed a high degree of reliability and internal consistency of the instrument. One hundred-ninety-four of the students $(98.5 \%)$ reported that they were satisfied with their professional choice. Phase I group of students had better quality of life averages when compared to those from Phase II group. Phase I group did not differ from the internship period (Phase III), concerning the Physical and Environmental Domains, but the Phase I students presented significantly $(\mathrm{p}<0.05)$ better scores in the Psychological and Use of time domains. Compared to Phase II students, those in Phase III presented better scores in the Physical and Environmental domains, but they presented lower scores in the Psychological domain (Table 2).

Female students from the private institution presented significantly lower $(\mathrm{p}<0.0001)$ scores than male students in all Veras-q domains. Students from the private institution also presented higher $(\mathrm{p}<0.0001)$ scores than students from the national survey, stratified by gender (Table 3 ) and

\section{Table 1. Demographic and socioeconomic characteristics of students from a private medical school, Salvador, Brazil, 2014}

\begin{tabular}{|c|c|}
\hline Variables & Characteristics \\
\hline \multicolumn{2}{|l|}{ Age (years) } \\
\hline Mean (standard deviation) & $21.0(2.85)$ \\
\hline Median & 21.6 \\
\hline Minimum & 17 \\
\hline Maximum & 32 \\
\hline \multicolumn{2}{|l|}{ Sex } \\
\hline Male $\quad n(\%)$ & $69(35.0)$ \\
\hline Female $\mathrm{n}(\%)$ & $128(65.0)$ \\
\hline \multicolumn{2}{|l|}{ Family income (american dollars) } \\
\hline$>$ US\$ $2,824.63$ n (\%) & $89(45.2)$ \\
\hline$\leq$ US\$2,824.63 n (\%) & $108(54.8)$ \\
\hline \multicolumn{2}{|l|}{ FIES loan } \\
\hline No $n(\%)$ & $138(70.1)$ \\
\hline Yes $n(\%)$ & $59(30.0)$ \\
\hline \multicolumn{2}{|l|}{ Period of course } \\
\hline Phase I - one to two years & $114(57.8)$ \\
\hline Phase II - three to four years $n(\%)$ & $53(27 \%)$ \\
\hline Phase III - five and six years $n(\%)$ & $30(15.2)$ \\
\hline
\end{tabular}


Table 2. Veras-q domains scores according to period of course of students from a private medical school, Salvador, Brazil, 2014

\begin{tabular}{|lcccc|}
\hline $\begin{array}{l}\text { Veras-q } \\
\text { Domain }\end{array}$ & $\begin{array}{c}\text { Phase I } \\
\mathbf{N}=\mathbf{1 1 4} \\
\text { mean (sd) }\end{array}$ & $\begin{array}{c}\text { Phase II } \\
\mathbf{N}=\mathbf{5 3} \\
\text { mean (sd) }\end{array}$ & $\begin{array}{c}\text { Phase III } \\
\mathbf{N}=\mathbf{3 0} \\
\text { mean (sd) }\end{array}$ & $\begin{array}{c}\text { Anova p-value } \\
\text { (two-tailed) }\end{array}$ \\
\hline Physical & $60.1(5.9)$ & $56.1(7.1)$ & $61.6(4.1)$ & 0.0001 \\
\hline Psychological & $58.6(4.4)$ & $57.1(5.1)$ & $53.5(3.5)$ & 0.0001 \\
\hline Use of time & $57.1(4.9)$ & $53.1(6.7)$ & $52.4(6.1)$ & 0.0001 \\
\hline Environmental & $71.1(4.1)$ & $66.2(4.7)$ & $69.5(2.9)$ & 0.0001 \\
\hline
\end{tabular}

Tukey HSD Post-hoc Test.

Physical: $\quad$ I vs II, $p=0.0003 ;$ II vs III, $p=0.0003$

Psychological: I vs III, $p=0.0001$; II vs III, $p=0.0016$

Use of time: I vs II, $p=0.0001$; I vs III, $p=0.0002$

Environmental: I vs II, $p=0.0001$; II vs III, $p=0.0016$

Table 3. Veras-q domains scores of students of a private medical school from Salvador, Brazil and from Veras-q National Survey according to sex, Brazil, 2014

\begin{tabular}{|c|c|c|c|c|c|c|c|}
\hline \multirow[t]{2}{*}{ Veras-q Domain } & \multicolumn{2}{|c|}{$\begin{array}{l}\text { Private medical school, } \\
\text { Salvador }\end{array}$} & \multirow[t]{2}{*}{$\mathbf{p}^{\mathrm{a}, \mathrm{b}}$} & \multicolumn{2}{|c|}{$\begin{array}{l}\text { Veras-q National } \\
\text { Survey }\end{array}$} & \multirow[t]{2}{*}{$\mathbf{p}^{\mathrm{a}, \mathrm{c}}$} & \multirow[t]{2}{*}{$\mathbf{p}^{\mathbf{b}, \mathbf{d}}$} \\
\hline & $\begin{array}{c}\text { Male }^{a} \\
N=69 \\
\text { mean (sd) }\end{array}$ & $\begin{array}{c}\text { Female }^{b} \\
N=128 \\
\text { mean (sd) }\end{array}$ & & $\begin{array}{c}\text { Male }^{c} \\
N=636 \\
\text { mean (sd) }\end{array}$ & $\begin{array}{c}\text { Female }^{d} \\
N=714 \\
\text { mean (sd) }\end{array}$ & & \\
\hline Physical & $61.2(2.1)$ & $57.4(3.6)$ & 0.0001 & $56.7(18.7)$ & $52.5(17.7)$ & 0.0001 & 0.0001 \\
\hline Psychological & $57.6(3.1)$ & $55.8(1.7)$ & 0.0001 & $52.8(16.1)$ & $49.4(15.9)$ & 0.0001 & 0.0001 \\
\hline Use of time & $56.4(2.6)$ & $51.4(3.4)$ & 0.0001 & $39.0(15.5)$ & $35.9(15.3)$ & 0.0001 & 0.0001 \\
\hline Environmental & $68.0(2.3)$ & $70.1(2.9)$ & 0.0001 & $57.8(13.1)$ & $56.7(13.1)$ & 0.0001 & 0.0001 \\
\hline
\end{tabular}

$a, b ; a, c ; b, d-t$ test.

domains and phases, except for Physical domain and Phase II $(\mathrm{p}<0.4352)$ (Table 4$)$.

The association of the predictive variables with the Veras-q scores was explored using linear regression analyses. The linear regression equation estimated significant decreases of 6.167 units (\%) in general Veras-q domain (Standard Error 2.161, $\mathrm{p}<0.005)$ and of 5.525 units (\%) in physical Veras-q domain (Standard Error 2.477, $\mathrm{p}<0.028$ ) in female that opted for being a physician due to the good salaries. Having a medical family influence increased in 4.793 units (\%) in physical Veras-q domain (Standard Error 2.373, $\mathrm{p}<0.046$ ). Females who did not choose medicine by vocation had on average 3.437 units (\%) lower Veras-q environment domain $(1.723, \mathrm{p}<0.048)$. Female students with excellent salaries perspectives had 3.693 units (\%) higher Veras-q environment domain (1.906 $\mathrm{p}<0.055)$. Male students with paid internship had 8.509 units (\%) higher Veras-q physical domain (Std. Error 3.481, p < 0.018) than those with no paid internship.

\section{Discussion}

The evaluation of the quality of life of the undergraduate medical student may contribute to the improvement of the medical course. In recent years, the private institution has evaluated students' quality of life $\mathrm{e}^{4,8}$ as a tool for curricular change and improvements in the course as a whole. In the present study, the students from the first two years (Phase I) showed the highest scores measured by Veras-q questionnaire. In a previous study among students from this private 
Table 4. Mean (standard deviation) of Veras-q domains scores according to phase of course of students from a private medical school from Salvador, Brazil, and from the National Veras-q Survey

\begin{tabular}{|c|c|c|c|c|}
\hline Phase & $\begin{array}{l}\text { Veras-q Domain } \\
\text { Mean (sd) }\end{array}$ & Private medical school & Veras-q National Survey & ${ }^{*} \boldsymbol{p}<$ \\
\hline \multirow[t]{5}{*}{ Phase I } & & $N=114$ & $N=459$ & \\
\hline & Physical & $60.1(5.9)$ & $54.4(18.2)$ & 0.0001 \\
\hline & Psychological & $58.6(4.4)$ & $51.9(16.7)$ & 0.0001 \\
\hline & Use of time & $57.1(4.9)$ & $38.3(16.5)$ & 0.0001 \\
\hline & Environmental & $71.1(4.1)$ & $60.3(12.8)$ & 0.0001 \\
\hline \multirow[t]{5}{*}{ Phase II } & & $N=53$ & $N=491$ & \\
\hline & Physical & $56.1(7.1)$ & $55.4(18.3)$ & 0.4352 \\
\hline & Psychological & $57.1(5.1)$ & $51.1(15.4)$ & 0.0001 \\
\hline & Use of time & $53.1(6.7)$ & $37.5(15.1)$ & 0.0001 \\
\hline & Environmental & $66.2(4.7)$ & $57.0(13.0)$ & 0.0001 \\
\hline \multirow[t]{5}{*}{ Phase III } & & $N=30$ & $N=400$ & \\
\hline & Physical & $61.6(4.1)$ & $53.4(18.3)$ & 0.0001 \\
\hline & Psychological & $53.5(3.5)$ & $49.9(16.2)$ & 0.0001 \\
\hline & Use of time & $52.4(6.1)$ & $36.2(14.6)$ & 0.0001 \\
\hline & Environmental & $69.5(2.9)$ & $54.0(12.8)$ & 0.0001 \\
\hline \multirow[t]{5}{*}{ All Phases } & & $N=197$ & $N=1,350$ & \\
\hline & Physical & $59.3(2.8)$ & $54.5(18.3)$ & 0.0001 \\
\hline & Psychological & $56.4(2.6)$ & $51.0(16.1)$ & 0.0001 \\
\hline & Use of time & $54.2(2.5)$ & $37.4(15.5)$ & 0.0001 \\
\hline & Environmental & $68.9(2.4)$ & $57.2(13.1)$ & 0.0001 \\
\hline
\end{tabular}

${ }^{*}$ t test.

institution, no clear trends were observed in the eight health-related quality of life domains, along the six-year-long course, measured by the 36 -item Short Form Health Survey questionnaire (SF-36). However, the mental component of the health-related quality of life were lower among students from the first year compared to those from the sixth year of the course ${ }^{4}$.

The majority of the private institution students reported satisfaction with their professional choice. In the first two years of course, after the intensive preparation to the medical course selection process, medical students present the greatest personal satisfaction with the career choice ${ }^{9}$. During the undergraduate course, medical students may experience stress due to sleep deprivation, academic pressure, excess of work, and exposure to suffering and death. In 2015, a qualitative study with the private institution medical students investigated factors associated to medical carrier choice. Students at the first years of the course, when questioned about the meaning of being a physician, reported as positive factors helping others and having personal satisfaction. Reported negative factors were: stress, work overload, and competitiveness. These factors demonstrate the students' concerns with their quality of life?

Higher family income was associated with greater satisfaction ${ }^{10}$. In 2013, a cross-sectional study evaluated the quality of life of students from this private medical school. Students who participated in a Brazilian loan program showed lower health-related quality of life scores even after stratification by gender, age, period of course, sleepiness, headache frequent episodes, practicing physical activity, having a car, having a housemaid, living with family, and living in a rented house 4 Only $59(30,0 \%)$ students evaluated by Veras-q participated in the national loan programme what may explain better quality of life scores of the other students (70\%) remaining in the sample.

Students from the third and fourth years had 
the worst quality of life scores. Medical students have many theoretical and practical activities such as monitoring activities, scientific initiation, university extension, and internship. These demands often interfere in the use of time to exercise, to take care of their own health, and to enjoy of family and friends relationships ${ }^{4,8,9}$. Since 2005 , this private institution has intensified curricular changes, focusing on the improvement of the quality of teaching, on the quality of life of its medical students. Since then, free time to study or having other activities has been integrated in medical student schedule ${ }^{11}$.

In the Phase I period, the Veras-q global mean score was higher when compared to Phase II and III periods. In the private medical school, scores were higher than in national sample. The Use of Time domain presented the most evident difference. Psychological and Physical domains were higher than the national average. These results may be explained by the curricular changes, including the close relationship between medical students and the Psychopedagogical Attention Center of the medical school ${ }^{12}$. Quality of life higher scores in Phase I may also be explained by the maturation process of the private institution curricular changes started in 2005 , a better adjustment of the schedules and less work overload as a consequence of effective interdisciplinarity in curricular components ${ }^{12}$.

Lower Veras-q quality of life was associated with the female gender in the private institution 2014 survey, specifically in all Veras-q domains. The linear regression equation estimated significant decreases in general and physical Veras- $\mathrm{q}$ domains ( $\mathrm{p}<0.005, \mathrm{p}<0.028$, respectively) in females that opted for being a physician due to the good salaries. Females who did not choose medicine by vocation presented lower Veras-q environment domain $(\mathrm{p}<0.048)$. Higher physical Veras-q domain in females $(\mathrm{p}<0.046)$ was associated with medical family influence. Excellent salaries perspectives predicted higher Veras-q environment domain $(p<0.055)$ in females. Paid internship predicted higher Veras-q physical domain $(p<0.018)$ in male students. The comparison of the private institution sample with the national sample showed higher scores for students of both genders from the private institution. Lower quality of life of medical student has been associated with female gender ${ }^{4}$. Female students who participate in the loan programme had the lowest mean score of health-related quality of life ${ }^{8}$.

This cross-sectional study design has its particular limitations. This design is not adequate to investigated cause-effect relationships. Furthermore, the reader must be alerted to the low proportion $(16.5 \%)$ of students, considering the institution census $(1,192)$. However, considering the calculated sample size of the study, its response rate was satisfactory (68\%). Finally, our study did not evaluate some social, psychological, and cultural factors that could interfere in the quality of life of medical students.

\section{Conclusions}

The quality of life of the medical students from in the study population was higher than that found in the national Veras-q study. Lower scores were associated with female gender. Choosing medical profession due to the good salaries was associated with decreases in general and physical Veras- $q$ domains in females. Curricular changes, incorporating active teaching-learning methodologies in all semesters; adjusted schedules, allowing free time for extracurricular activities, and lower work overload, as consequences of effective interdisciplinarity in curricular components, may have contributed to higher students' QoL.

\section{References}

1. The World Health Organization Quality of Life Assessment (WHOQOL): position paper from the World Health Organization. Soc Sci Med 1995; 41: 1403-9.

2. Programme on mental health. WHOQOL User Manual (1998, rev. 2012). Division of mental health and prevention of substance abuse, World Health Organization (WHO). Retrieved 17. December 2014 (http://apps.who. int/iris/bitstream/10665/77932/1/WHO_HIS_HSI_ Rev.2012.03_eng.pdf?ua=1).

3. Dyrbye LN, Thomas MR, Shanafelt TD. Systematic review of depression, anxiety, and other indicators of psychological distress among US and Canadian medical students. Acad Med 2006; 81 (4): 354-73.

4. Lins L, Carvalho FM, Menezes MS, Porto-Silva L, Damasceno H. Health-related quality of life of medical students in a Brazilian student loan programme. Perspect Med Educ 2016; 5 (4): 197-204.

5. Brasil. Ministério da Educação; Conselho Nacional de 
Educação, Câmara de Educação Superior. Diretrizes Curriculares do Curso de Medicina 2014-Resolução no 3, de 20 de junho de 2014. Brasília; 2014.

6. Tempski P, Perotta B, Pose RA, Vieira JE. A questionnaire on the quality of life of medical students. Med Educ 2009; 43 (11): 1107-8.

7. Furr RM. Scale construction and psychometrics for social and personality psychology. London: SAGE Publications; 2011.

8. Lins L, Carvalho FM, Menezes MS, Porto-Silva L, Damasceno H. Health-related quality of life of students from a private medical school in Brazil. Int J Med Educ 2015; 6: 149-54.

9. Lins L, Damasceno H, Barreto F, Menezes M, Santos RJ, Herbas S, et al. Factors associated to the choice of the medical career in northeast Brazil. J Research in Medical
Education \& Ethics (JRMEE) 2015; 5: 25-31.

10. Vera-Villarroel P, Atenas KC, Pavez P, Lillo S, Bello F, Díaz N, et al. Money, age and happiness: association of subjective wellbeing with socio-demographic Variables. Rev Latinoam Psicol 2012; 44 (2): 155-63.

11. Soliani ML. Eu, Diretora de uma Escola Médica, e o Bem-estar do Estudante de Medicina. Cadernos ABEM 2010;1 (6): 36-46.

12. Menezes M. O desafio de construir sem destruir-estratégias para realização de reforma curricular em curso médico tradicional. Cadernos ABEM 2016; 1 (12): 83-6.

13. De Arruda Martins M, Tempski P, Panse Silverira OS Coordinadores. "Projeto VERAS. Vida de estudante e Residente na Área de Saúde”. Faculdade de Medicina da Universidade de São Paulo. São Paulo, 2011. http:// www.apex.fm.usp.br/cgi-bin/prelogin.cgi 